Article

\title{
Inclusive Leadership and Education Quality: Adaptation and Validation of the Questionnaire "Inclusive Leadership in Schools" (LEI-Q) to the Italian Context
}

\author{
Emilio Crisol Moya ${ }^{1}$, Tiziana Molonia ${ }^{2}$ (1) and María Jesús Caurcel Cara ${ }^{3, *(1)}$ \\ 1 Department of Didactics and School Organization, University of Granada, 18071 Granada, Spain; \\ ecrisol@ugr.es \\ 2 Escuela Primaria, I.C. “La Pira Gentiluomo”i, 98149 Messina, Italy; tizianamolonia@gmail.com \\ 3 Department of Developmental and Educational Psychology, Faculty of Education, University of Granada, \\ 18071 Granada, Spain \\ * Correspondence: caurcel@ugr.es; Tel.: +34-958-249-896
}

Received: 30 May 2020; Accepted: 30 June 2020; Published: 2 July 2020

\begin{abstract}
The United Nations Sustainable Development Programme for 2030 has established the principles of sustainable action for today's society, one of which is to achieve quality and more inclusive education. Our society has reached the stage where quality education is no longer a privilege of a few, but a fundamental right. Therefore, not achieving quality education is equivalent to not having had the opportunity to grow and develop as fully as one is entitled to in a free and just society, which needs inclusive leadership. The objective in this study is the validation of the instrument "Inclusive Leadership in Schools" for the Italian context. The methods used are content validity through expert judgement; construct validity through exploratory and confirmatory factor analysis; and reliability through Cronbach's alpha coefficient and the split-half method. The results reveal that both the version for school administrators and teachers and the version for families have optimal levels of validity and reliability for measuring the degree of inclusive leadership in Italian schools. The results suggest that inclusive leadership effects are expected to operate most closely via their influence on developing the improvement of teaching and learning quality and promoting a favourable school climate and culture that emphasize high expectations and quality education.
\end{abstract}

Keywords: inclusive education; leadership; psychometric properties; quality; families; teaching teams

\section{Introduction}

"The United Nations (UN) launched its Sustainable Development Goals in 2015 to address the greatest challenges facing the world's populations" [1]. These goals are a continuation of the Millennium Development Goals [2], which include quality education.

Education is the basis for improving our lives and sustainable development. In addition to improving people's quality of life, access to inclusive and equitable education can help provide local people with the tools to develop innovative solutions to the world's greatest problems [3]. Comprehensive and increasingly systematic reviews on leaders and leadership demonstrate that the quality of leadership can be a critical factor in supporting quality education improvement.

Leadership has significant effects on school organization, the way teachers work, student outcomes and the effectiveness of leaders [4-6].

For school leaders, the crucial point of attention must be the attitudes of the teaching staff, since it is their activities that have a direct consequence on the quality of learning and teaching, and on obtaining the best results from students. 
In schools, the directors are no longer the only leaders; instead, leadership responsibility is shared. For the management of the organization, according to De la Fuente-Anuncibay et al. [7] and Agasisti et al. [8], this means that a combination of functions is necessary, so that there is a balance between flexibility and control, and between its external and internal orientation. They need to formulate policies to fit the environment, to achieve objectives, to integrate people so as to obtain a good social atmosphere, and to find a balance between authority, order, rationality and internal coordination in the administration of the organization.

In addition to transformational, distributive and pedagogical leadership, the literature increasingly points to the concept of inclusive leadership [9-11]. The role of inclusive leadership refers to the participation and representation of all teachers, administrators, the school community and students.

Inclusive leadership through collegial leadership focuses on improving the learning conditions of all students, is committed to the values of inclusion, and encourages and supports all processes of reflection and discussion among all members of the school [11-14].

As indicated by León et al. [15], the tasks and/or functions performed by the management team to meet the goals of an inclusive school are:

(1) openness to the community (it carries out initiatives from within the school);

(2) the school as an inclusive community (it undertakes actions to generate a shared vision, promoting participation, cooperation and dynamics of positive reflection towards diversity);

(3) it is a professional learning community (it promotes training, the professional development of teachers and the creation of professional learning communities); and

(4) management of teaching-learning processes (it carries out initiatives to improve and promote coordination in the teaching and learning process of teachers).

In Italy, education is structured as follows: three years of non-compulsory preschool education (from three to six years of age), five years of primary education (from six to ten years of age), three years of lower (level two) secondary education (from ten to thirteen years of age), and upper (level three) secondary education (from fourteen to eighteen years of age). In the case of Spain, it is structured with six years of non-compulsory preschool education (from zero to six years of age), six years of primary education (from six to twelve years of age), four years of secondary education (from twelve to sixteen) and lastly, post-compulsory secondary education (until the age of eighteen).

The current trend in the European Union consists of developing a policy, the aim of which is to integrate students with special educational needs (SEN) in ordinary schools. In Spain and in Italy common concepts are used to refer to this group of students. In both countries, all students with disabilities are included, with there being a strong relation between SEN and learning difficulties [16].

The inclusion of SEN students in both countries takes place through cooperation between the schools, the families and the health services [16]. The SEN student needs the support of a number of specialists who work together to identify what their potential is and what interventions can ensure the best results. Those responsible for providing the diagnosis of the student's psycho-physical condition-functional potential, needs, professional assistance, and materials required for their complete development-are, in Spain, the Educational and Psychological Orientation Teams, and in Italy, the teams from their local health authority units (AUSL). In Italy, the education system has traditionally been highly centralized and bureaucratic, and the role of the management team varies considerably due to the effect of school autonomy [17-19]. The team takes a strategic role in the exercise of management activities, direction and promotion of the innovations stipulated by Law 107 of 2015 by listening to students, families and the community, thus implementing the concept of school leadership that looks at inclusion. It is also true that, to this day, the management of the self-evaluation system is still entrusted to a narrow group of collaborators.

Given the great interest in the literature on school leadership, numerous studies have developed instruments with the objective of measuring its practice [20-22]. One of the latest is that developed by a group of Spanish researchers that gave rise to the "Inclusive Leadership in Schools" questionnaires 
(LEI-Q) [23]. Its purpose is to discover the opinion of the teaching staff and the families regarding the degree to which school management promotes inclusion in primary and secondary schools in the city of Granada (Spain), and to identify the strengths and weaknesses of the leadership exercised by the management to promote inclusion.

The translation, adaptation and validation of the teacher and family questionnaires for the Italian context is the subject of study of this investigation.

\section{Methods}

\subsection{Statement of the Problem}

The purpose of this research is to adapt and validate the instrument "Inclusive Leadership in schools" (LEI-Q) [23], which is the version for teachers and family members that has been adapted to the Italian context. The objectives pursued are: (a) to study the validity of content through the agreement and consensus of expert judgement; (b) assess the stability of the questionnaire by measuring the agreement using the Kendall tau-b correlation coefficient; (c) corroborate the validity of the understanding of the instrument through its application to a pilot sample; (d) determine the multidimensionality of the construct through exploratory factor analysis; (e) confirm the multidimensionality of the construct through confirmatory factor analysis; and (f) analyse the reliability of the questionnaire.

\subsection{Participants}

A double sampling selection process was carried out: first, a non-probabilistic sampling of convenience was used for the sample community of schools; second, for the people to whom the instruments were administered, no type of sampling was employed, but rather an attempt was made to reach the maximum number of the population.

We had access to eight of the twenty-two state schools of preschool, primary and secondary education in the city of Messina (Italy) to complete the pilot study, $56.60 \%$ participants being from the central area of the city, $21.20 \%$ from the north and $22.20 \%$ from the south, all of them characterized by an average socioeconomic level (84.00\%).

Of the total population of teaching staff of 1240,293 teachers from preschool $(8.20 \%)$, primary $(46.20 \%)$ and secondary (45.40\%) education collaborated, with an age range between 35 and 67 years old $(\mathrm{M}$ age $=51.67$ years, $\mathrm{SD}=7.32)$, of whom 21 were men $(7.20 \%)$ and 272 were women $(92.8 \%)$. The sample comprised teachers with diverse professional experience, ranging from fewer than five years $(10.50 \%)$ to more than thirty years $(25.20 \%)$; their initial training was mainly university studies $(74.40 \%)$ and baccalaureate $(24.2 \%) ; 72.1 \%$ were curricular teachers and $24.50 \%$ support staff. The sample obtained a $95 \%$ confidence level and a 5\% margin of error, according to the mathematical calculations of representative sample size.

Of a total of 2106 families, 928 families participated. The sample obtained a degree of confidence of $95 \%$ and a margin of error of less than $2.5 \%$, according to the mathematical calculations of representative sample size, which is below the error usually assumed in educational research (5\%) which would involve a sample size of 325 . Women ( $\mathrm{M}$ age $=42.61, \mathrm{SD}=5.41$, age range $=24$ to 64 years old) were more participatory with $79.90 \%$ compared to $20.10 \%$ men ( $\mathrm{M}$ age $=45.65, \mathrm{SD}=5.46$, age range $=31$ to 63 years old). Of the men, $56.50 \%$ studied secondary education, and $26.30 \%$ higher education; those in employment were mainly administrative and/or commercial personnel $(40.30 \%)$ and $12.9 \%$ in the liberal professions. For the women, $48.90 \%$ studied secondary education and $28.70 \%$ higher education; $39.90 \%$ were housewives, $24.00 \%$ worked in administrative or commercial jobs and $13.2 \%$ worked in the education sector. The majority were married $(87.5 \%)$ and had either a low-medium $(46.3 \%)$ or medium socioeconomic level (44.2\%). 


\subsection{Evaluation Instruments}

The LEI-Q questionnaire [23] is of the Likert type, with four response options (1. Not implemented, 2. Partially implemented, 3. Substantially implemented and 4. Fully implemented). The version aimed at school teachers and administrators is composed of forty items, distributed in two dimensions. The first is "The school as an inclusive community" (items 1-18, Dimension I), which analyses the management team's initiatives to strengthen the opening up of the school to the educational community and its environment, encourage participation, promote diversity, establish measures to foster improvement and protect the school from situations that hinder the success of everyone, and equality of opportunities. The second is the "Management of the teaching-learning processes and development of teaching professionalism," which comprises items 19-40 (Dimension II). These evaluate the conditions that the management team develops to foster the inclusion of all students in the teaching-learning processes and to create a professional learning community based on shared and committed values of student diversity. The questions directed at families are composed of twenty-six items, also distributed in two dimensions: "The school as an inclusive space" (items 1-17, Dimension I), which analyses the actions developed by the management team to boost participation, promote diversity and prevent and control conflicts in the institution; and "Openness to the community" (items 18-26, Dimension II), to achieve the goals set out above.

\subsection{Procedure}

Permission to carry out the research was obtained from the schools' management teams. The teaching staff and family members were informed of the purpose of the study and of their rights as participants, with anonymity and confidentiality of the data being guaranteed.

The information was gathered over a period of two months in person with questionnaires either on paper or online through the Google Docs link sent from the email of the management team.

\subsection{Data Analysis}

As a method to test the validity of the content, expert judgements/opinions were used. To analyse the metric properties of each item, basic descriptive coefficients (mean, dispersion, kurtosis and asymmetry) were used, with SPSS version 26.0. The validity of the construction was carried out through exploratory factor analysis (EFA) --Factor Analysis version 10.10.01 [24] - to determine the goodness of the fit and the validity of the scale [25], and confirmatory factor analysis (CFA)-M-PLUS-to establish the validity and reliability of the fit of the model [26]. The internal consistency of the instrument was calculated using Cronbach's alpha coefficient and the split-half method, using SPSS version 26.0. The tests to determine sex differences (Student's $t$ ) were also performed with SPSS 26.0.

\section{Results}

\subsection{Revision, Translation and Adaptation to the Italian Socio-Educational Context}

Because the instrument was created for a different population, to attain the validity of the content, a translation, adaptation and standardization process was required. The items were first translated into Italian, then re-translated into the original language from the Italian translation by a native translator (back-translation), taking into consideration four criteria pointed out by Martín-Arribas [27]: "the cultural context where adaptation is going to take place; technical aspects of the development and adaptation of the test; test administration; interpretation of the scores." Subsequently, a member of the management team from one of the participating schools in the city of Messina corroborated the items to check if the questions were relevant for the school staff and for the families. 


\subsection{Content Validation}

For content validity, expert judgement was used, with this being a validation method useful for verifying the reliability of a survey [28].

Out of the total of experts, five belonged to the University of Messina (three men and two women), who were testing and psychometric specialists, with between ten and forty-five years of experience and who were not involved in the study in order to obtain the greatest possible objectivity; and five teachers (two men and three women), who were teachers of preschool $(n=1)$, primary $(n=2)$ and secondary $(n=2)$ education in state schools in the city of Messina with at least ten years of experience. The experts had to validate the items based on the following criteria: clarity, degree of coherence with the dimension and relevance with the object of study, on a scale of 1 (lowest value) to 4 (highest value).

For this study, the degree of agreement between the experts was verified through the measurement of the agreement percentage, the intraclass correlation coefficient and the Kendall coefficient. For the version aimed at management and teachers, the values obtained of the Cronbach alpha coefficient $(\alpha)$ were 0.971 (Dimension I) and 0.975 (Dimension II) and were, therefore, excellent. Moreover, the results obtained with respect to the intraclass correlation coefficient (IC) were excellent with values 0.966 (Dimension I) and 0.973 (Dimension II). With respect to the Kendall coefficient (W), the values were significant, albeit low: 0.252 (Dimension I) and 0.179 (Dimension II).

For the version intended for families, the values obtained of the Cronbach alpha coefficient $(\alpha)$ were 0.952 (Dimension I) and 0.972 (Dimension II) and were, therefore, excellent. Moreover, the results obtained with respect to the intraclass correlation coefficient (IC) were excellent with values of 0.947 (Dimension I) and 0.972 (Dimension II). With respect to the Kendall coefficient (W), the values were significant, albeit low: 0.203 (Dimension I) and 0.169 (Dimension II).

\subsection{Construct Validity}

Before undertaking EFA, the descriptive values of the study were calculated (Tables 1 and 2), following the steps recommended by experts [29], and because the dispersion tests (asymmetry and kurtosis) presented values between -1 and +1 [30], none of the items from either of the questionnaires was eliminated.

After the completion of EFA in accordance with the proposal of Lloret-Segura et al. [31], the underlying structure of the instrument addressed to teaching and management teams was compared to the tasks and/or functions that the management team had to fulfil in order to achieve the goals of an inclusive school $[15,23,32,33]$. These enabled the previous results of the research of León et al. [23] to be replicated as indicated by Hair et al. [34]. For AFE, the method of parallel analysis (PA) with promin rotation was used to maximize factor simplicity, determining the two factors as recommended for PA [35]. Bartlett's statistic [3198.7 ( $\mathrm{df}=780 ; p=0.000010)$ ] and the Kaiser-Meyer-Olkin test (KMO) [=0.973], were used to check whether the sample came from populations with the same variance and whether it presented an appropriate fit for the sample. A good fit for the data to be subjected to factorial analysis was found. The two factors obtained explained $67 \%$ of the total variance; the goodness of fit index (GFI) was 0.997, the adjusted goodness of fit index (AGFI) gave a value of 0.996, the comparative fit index (CFI) was 1.005, and the root mean square of residuals (RMSR) was 0.0373 , with an expected average value of RMSR for an acceptable value being 0.0585 according to Kelley's [36] criterion. All these data indicate an excellent fit for these items and an acceptable model.

As can be seen in the matrix of rotated factors (Table 3), no item was eliminated since they all gave factorial weights with an absolute value higher than 0.40 [31]. Thus, after analysing and evaluating the weight of each variable according to the factor, the final questionnaire was as follows: Factor 1: "Management of the teaching-learning processes and the professional development of the teachers" included twenty-eight items and Factor II: "The school as an inclusive community" included twelve items.

Authors such as Carretero-Dios and Pérez [37] and Clark and Watson [38] recommend carrying out a correlation study to ensure the homogeneity of each dimension. The correlational analysis of 
the final version of the scale for the teaching team gave significant results at the 0.01 (bilateral) levels. The correlation between the score of each item and the total score in each one of the components shows that there was a positive correlation with the corresponding theoretical dimension and with the total score of the other dimension. The values obtained for each item for Factor 1 varied between $\mathrm{r}=0.306$, $p<0.000$ and $\mathrm{r}=0.645, p<0.000$, and for Factor 2 they varied between $\mathrm{r}=0.565, p<0.000$ and $\mathrm{r}=0.852$, $p<0.000$. The two factors showed a very good relationship $(\mathrm{r}=0.843, p<0.000)$.

In the case of the questionnaire addressed to families, the Bartlett statistic [1051.6 ( $\mathrm{df}=325$; $p=0.000010)]$ and the Kaiser-Meyer-Olkin $(\mathrm{KMO})$ test $[=0.977]$ indicated a good fit of the data to be submitted to factorial analysis. The two factors obtained explained $60.50 \%$ of the total variance, the GFI was 0.997, the AGFI gave a value of 0.997, the CFI was 1.000 and the RMSR was 0.0297, with the expected average value of RMSR for a model being acceptable according to Kelley's (1935) criterion at 0.0329. All these data indicate an excellent fit for these and an acceptable model.

As can be seen in the matrix of rotated factors (Table 4), no item was eliminated since all presented factorial loads had an absolute value higher than 0.40 [31]. In this way, after analysing and evaluating the weight of each variable according to the factor, we determined two factors: Factor 1: "Openness to the community," with fifteen items; and Factor 2: "The school as an inclusive space," with eleven items.

Table 1. Description of the items of the Inclusive Leadership in Schools questionnaire (LEI-Q) in the version for the teaching staff.

\begin{tabular}{|c|c|c|c|c|c|}
\hline Variables & Mean & Standard Deviation & Variance & Skewness & Kurtosis \\
\hline V01 & 2.93 & 0.74 & 0.547 & -0.336 & -0.111 \\
\hline V02 & 2.87 & 0.75 & 0.559 & -0.270 & -0.217 \\
\hline V03 & 2.47 & 0.90 & 0.809 & -0.044 & -0.771 \\
\hline V04 & 2.78 & 0.84 & 0.701 & -0.242 & -0.537 \\
\hline V05 & 2.58 & 0.94 & 0.885 & -0.110 & -0.872 \\
\hline V06 & 2.91 & 0.78 & 0.613 & -0.356 & -0.271 \\
\hline V07 & 3.02 & 0.80 & 0.634 & -0.525 & -0.142 \\
\hline V08 & 2.94 & 0.79 & 0.620 & -0.263 & -0.538 \\
\hline V09 & 2.73 & 0.86 & 0.738 & -0.124 & -0.693 \\
\hline V10 & 2.82 & 0.82 & 0.674 & -0.360 & -0.330 \\
\hline V11 & 2.89 & 0.80 & 0.641 & -0.328 & -0.384 \\
\hline V12 & 2.70 & 0.89 & 0.784 & -0.292 & -0.600 \\
\hline V13 & 2.83 & 0.87 & 0.756 & -0.413 & -0.452 \\
\hline V14 & 2.94 & 0.82 & 0.668 & -0.482 & -0.207 \\
\hline V15 & 3.04 & 0.78 & 0.610 & -0.498 & -0.162 \\
\hline V16 & 2.92 & 0.81 & 0.650 & -0.334 & -0.450 \\
\hline V17 & 2.87 & 0.87 & 0.759 & -0.405 & -0.513 \\
\hline V18 & 2.96 & 0.84 & 0.705 & -0.450 & -0.426 \\
\hline V19 & 2.94 & 0.84 & 0.710 & -0.371 & -0.569 \\
\hline V20 & 2.85 & 0.85 & 0.715 & -0.321 & -0.522 \\
\hline V21 & 2.96 & 0.84 & 0.705 & -0.472 & -0.364 \\
\hline V22 & 3.01 & 0.82 & 0.669 & -0.589 & -0.083 \\
\hline V23 & 2.86 & 0.84 & 0.705 & -0.328 & -0.506 \\
\hline V24 & 3.03 & 0.86 & 0.743 & -0.566 & -0.393 \\
\hline V25 & 3.00 & 0.76 & 0.580 & -0.418 & -0.172 \\
\hline V26 & 3.00 & 0.82 & 0.662 & -0.496 & -0.266 \\
\hline V27 & 2.95 & 0.85 & 0.721 & -0.500 & -0.331 \\
\hline V28 & 2.79 & 0.87 & 0.759 & -0.267 & -0.634 \\
\hline V29 & 3.05 & 0.81 & 0.646 & -0.522 & -0.256 \\
\hline V30 & 2.87 & 0.88 & 0.772 & -0.387 & -0.575 \\
\hline V31 & 2.99 & 0.86 & 0.730 & -0.580 & -0.258 \\
\hline V32 & 3.10 & 0.83 & 0.680 & -0.619 & -0.234 \\
\hline V33 & 3.01 & 0.82 & 0.672 & -0.541 & -0.208 \\
\hline V34 & 3.06 & 0.82 & 0.669 & -0.521 & -0.365 \\
\hline V35 & 2.99 & 0.82 & 0.665 & -0.435 & -0.401 \\
\hline V36 & 3.03 & 0.73 & 0.617 & -0.478 & -0.225 \\
\hline V37 & 3.12 & 0.80 & 0.633 & -0.754 & 0.275 \\
\hline V38 & 2.94 & 0.85 & 0.720 & -0.354 & -0.622 \\
\hline V39 & 3.16 & 0.78 & 0.601 & -0.646 & -0.072 \\
\hline V40 & 3.03 & 0.81 & 0.648 & -0.444 & -0.416 \\
\hline
\end{tabular}


Table 2. Description of the items of the LEI-Q questionnaire in the version for family members.

\begin{tabular}{cccccc}
\hline Variables & Mean & Standard Deviation & Variance & Skewness & Kurtosis \\
\hline V01 & 2.44 & 0.89 & 0.783 & 0.052 & -0.720 \\
V02 & 2.40 & 0.88 & 0.774 & 0.004 & -0.739 \\
V03 & 2.45 & 0.98 & 0.951 & 0.047 & -0.991 \\
V04 & 2.51 & 0.96 & 0.926 & -0.054 & -0.952 \\
V05 & 2.67 & 0.94 & 0.884 & -0.227 & -0.832 \\
V06 & 2.43 & 0.96 & 0.921 & 0.014 & -0.960 \\
V07 & 2.38 & 0.91 & 0.825 & 0.095 & -0.796 \\
V08 & 2.49 & 0.94 & 0.889 & -0.006 & -0.899 \\
V09 & 2.24 & 0.95 & 0.911 & 0.238 & -0.922 \\
V10 & 2.53 & 0.93 & 0.856 & -0.001 & -0.848 \\
V11 & 2.60 & 0.95 & 0.900 & -0.162 & -0.882 \\
V12 & 2.58 & 0.89 & 0.787 & -0.135 & -0.704 \\
V13 & 2.47 & 0.91 & 0.830 & -0.012 & -0.807 \\
V14 & 2.58 & 0.92 & 0.848 & -0.066 & -0.833 \\
V15 & 2.58 & 0.86 & 0.740 & -0.068 & -0.644 \\
V16 & 2.57 & 0.89 & 0.790 & -0.076 & -0.727 \\
V17 & 2.66 & 0.92 & 0.851 & -0.177 & -0.807 \\
V18 & 2.36 & 0.91 & 0.828 & 0.142 & -0.784 \\
V19 & 2.59 & 0.90 & 0.804 & -0.144 & -0.729 \\
V20 & 2.75 & 0.87 & 0.762 & -0.226 & -0.657 \\
V21 & 2.53 & 0.90 & 0.800 & -0.068 & -0.746 \\
V22 & 2.39 & 0.87 & 0.757 & -0.005 & -0.720 \\
V23 & 2.59 & 0.93 & 0.853 & -0.133 & -0.818 \\
V24 & 2.29 & 1.01 & 1.017 & 0.136 & -0.999 \\
V25 & 2.51 & 0.88 & 0.779 & -0.037 & -0.714 \\
V26 & 2.55 & 0.97 & 0.802 & -0.062 & -0.751 \\
\hline
\end{tabular}

Table 3. Matrix of rotated factors LEI-Q (teaching and management teams).

\begin{tabular}{|c|c|c|}
\hline Variables & Factor 1 & Factor 2 \\
\hline V01 & & 0.727 \\
\hline V02 & & 0.861 \\
\hline V03 & & 0.979 \\
\hline V04 & & 0.963 \\
\hline V05 & & 0.998 \\
\hline V06 & & 0.751 \\
\hline V07 & & 0.599 \\
\hline V08 & & 0.748 \\
\hline V09 & & 0.779 \\
\hline V10 & & 0.635 \\
\hline V11 & & 0.458 \\
\hline V12 & & 0.579 \\
\hline V13 & 0.589 & \\
\hline V14 & 0.800 & \\
\hline V15 & 1.016 & \\
\hline V16 & 0.691 & \\
\hline V17 & 0.515 & \\
\hline V18 & 0.758 & \\
\hline V19 & 0.687 & \\
\hline V20 & 0.587 & \\
\hline V21 & 0.693 & \\
\hline V22 & 0.811 & \\
\hline V23 & 0.760 & \\
\hline V24 & 0.938 & \\
\hline V25 & 0.676 & \\
\hline V26 & 0.868 & \\
\hline V27 & 0.889 & \\
\hline V28 & 0.748 & \\
\hline V29 & 0.924 & \\
\hline
\end{tabular}


Table 3. Cont.

\begin{tabular}{ccc}
\hline Variables & Factor $\mathbf{1}$ & Factor 2 \\
\hline V30 & 0.718 & \\
V31 & 0.911 & \\
V32 & 1.038 & \\
V33 & 0.854 & \\
V34 & 0.825 & \\
V35 & 1.035 & \\
V36 & 0.981 & \\
V37 & 0.851 & \\
V38 & 0.492 & \\
V39 & 0.916 & \\
V40 & 0.799 & \\
\hline
\end{tabular}

Table 4. Matrix of rotated factors LEI-Q (families).

\begin{tabular}{ccc}
\hline Variables & Factor 1 & Factor 2 \\
\hline V01 & & 0.793 \\
V02 & & 0.958 \\
V03 & & 0.885 \\
V04 & & 0.707 \\
V05 & & 0.474 \\
V06 & & 0.801 \\
V07 & & 0.752 \\
V08 & & 0.409 \\
V09 & & 0.718 \\
V10 & 0.562 & 0.559 \\
V11 & 0.449 & \\
V12 & 0.517 & \\
V13 & 0.667 & \\
V14 & 0.649 & \\
V15 & 0.839 & \\
V16 & 0.840 & \\
V17 & 0.673 & \\
V18 & 0.928 & \\
V19 & 1.062 & \\
V20 & 0.891 & \\
V21 & 0.642 & \\
V22 & 0.729 & \\
V23 & & \\
V24 & 0.756 & \\
V25 & 0.716 & \\
V26 & &
\end{tabular}

The correlational analysis of the final version of the scale for families gave significant results at 0.01 (bilateral) levels. The correlation between the score of each item and the total score in each one of the components shows that there was a positive correlation with the corresponding theoretical dimension and with the total score of the other dimension. The values obtained for each item for Factor 1 varied between $\mathrm{r}=0.423, \mathrm{i}<0.000$ and $\mathrm{r}=0.745, p<0.000$, and for Factor 2 they varied between $\mathrm{r}=0.361, p<0.000$ and $\mathrm{r}=0.668, p<0.000$. The two factors showed a very good relationship $(\mathrm{r}=0.859$, $p<0.000)$. 


\subsection{Confirmatory Factor Analysis}

With the objective of contrasting the model built through EFA for the questionnaire version aimed at management and teaching, we performed a confirmatory analysis through M-PLUS, with the structure that we constructed from the one obtained in EFA being as follows (Figure 1):

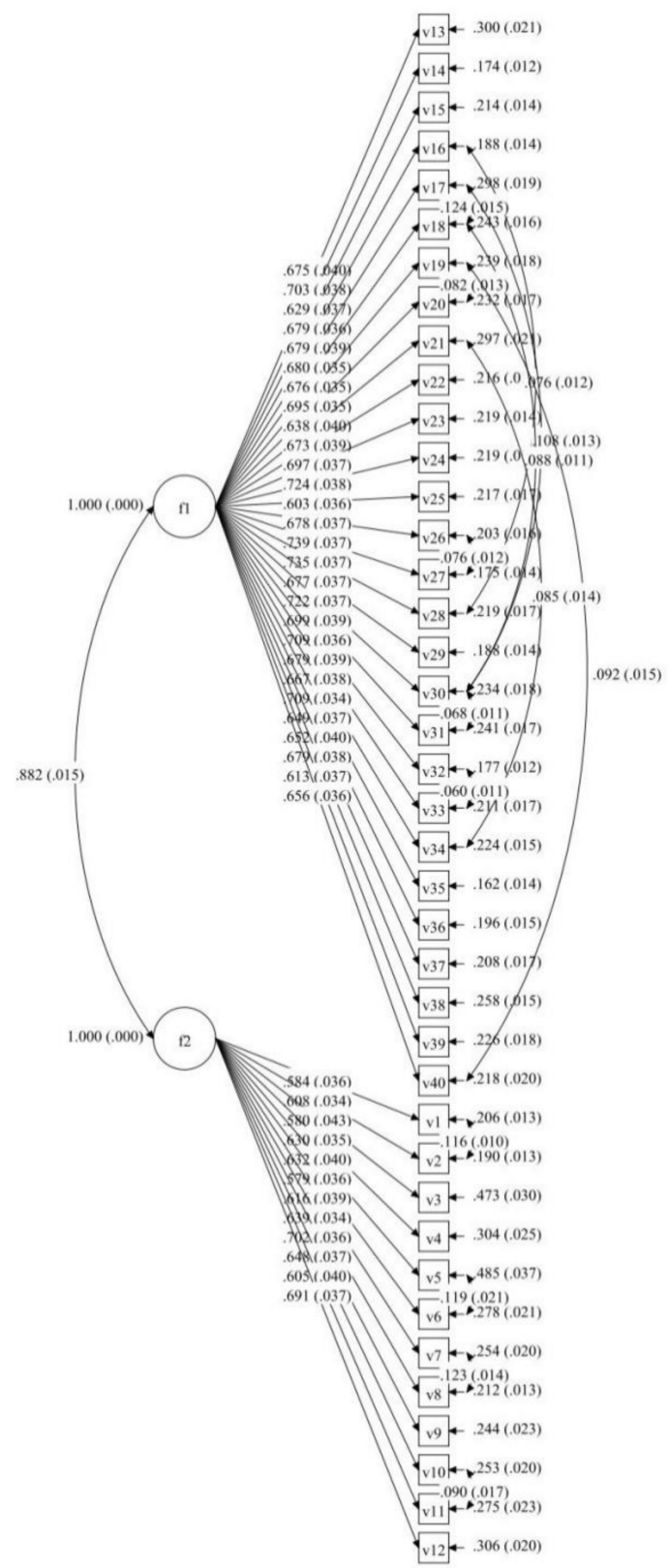

Figure 1. Proposed Model. Confirmatory factorial analysis for LEI-Q (teaching and management teams).

The results obtained through M-PLUS indicate a good fit of the model [34], with the values reached being favourable and acceptable both for RMSEA (root mean square error of approximation), at 0.058 , and for SRMR (standardized root mean squared residual), at 0.041. The CFI (comparative fit index) was 0.925 and the TLI (Tucker-Lewis index) was 0.919.

Furthermore, for these indices of fit, it is considered important for the CFA to provide composite reliability (CR) [39] data for each critical dimension, as it analyses the relations between the item responses and the latent variable measured [40], as well as the average variance extracted (AVE) [40] in 
order to study the validity of the scale. The CR value should be higher than 0.70 and the AVE should be above 0.50 [34]. The CR for Factor 1 was 0.981 and the AVE was 0.636, while for Factor 2 the CR was 0.944 and the AVE was 0.599 .

The structure constructed from the one obtained in the exploratory factor analysis of the questionnaire addressed to families is as follows (Figure 2):

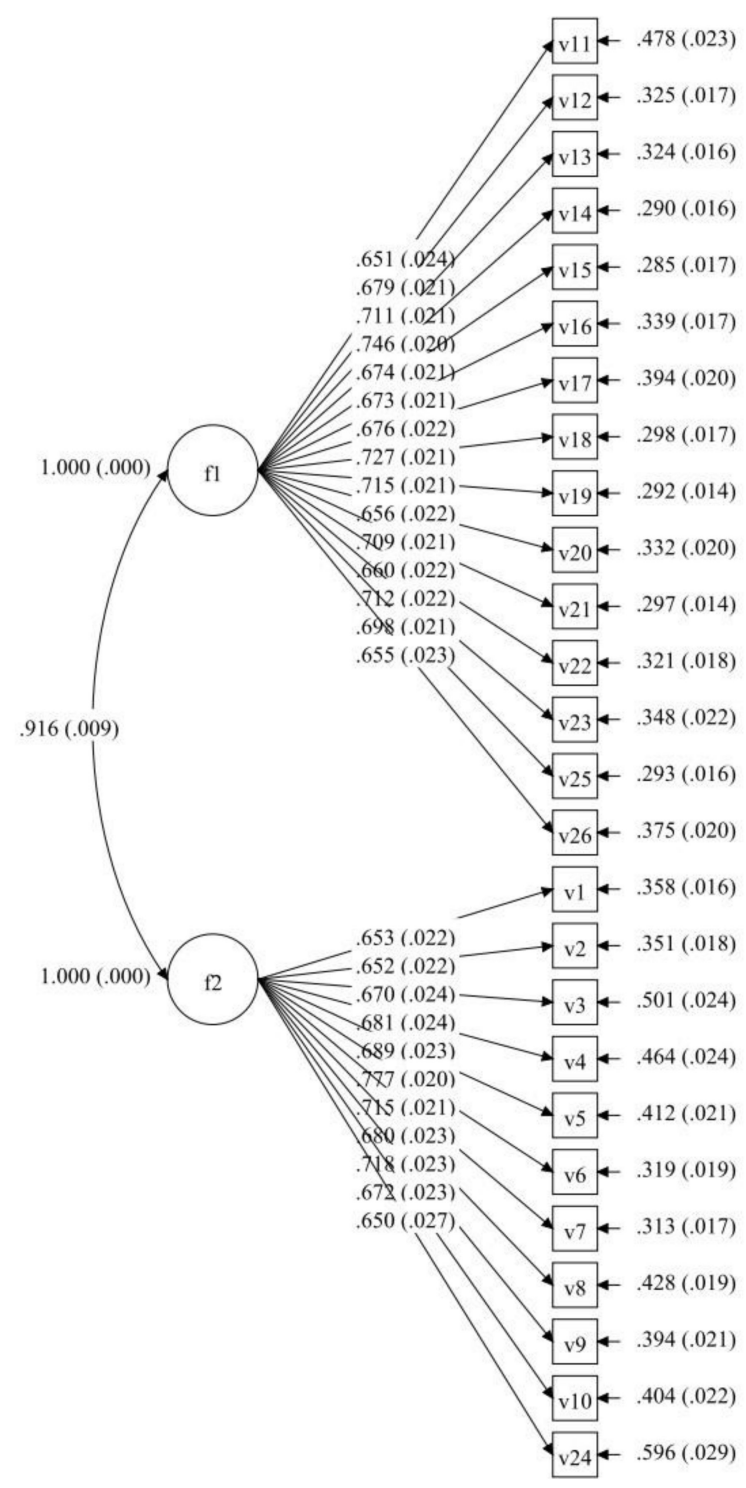

Figure 2. Proposed Model. Confirmatory factorial analysis for LEI-Q (families).

The results of the AFC for the questionnaire addressed to the families were equally favourable and acceptable [34] for RMSEA (0.052) and for SRMR (0.031), CFI (0.939) and TLI (0.933), demonstrating the goodness of the model. The CR for Factor 1 was 0.946 and the AVE was 0.554, and for Factor 2 the CR was 0.929 and the AVE was 0.560 .

\subsection{Calculation of Reliability}

The reliability methods that have been chosen are Cronbach's alpha coefficient and the split halves method. Both methods are considered the most used by social researchers [41]. For the questionnaire addressed to the teaching and management teams, with forty variables and two dimensions, the reliability coefficient was 0.985 , obtained with a confidence level of $95 \%(p<0.05)$, while for Factor 1, 0.983 was obtained (with twelve elements), and for Factor 2 (with twenty-eight elements), 0.944 
was obtained. For the family questionnaire, for the total of twenty-six variables, a value of 0.968 was obtained; 0.955 was obtained for Factor 1 (with fifteen elements) and 0.924 for Factor 2 (with eleven elements). As can be seen, a satisfactory Cronbach's alpha was obtained for both questionnaires in their totality, and it was also satisfactory for each of the factors, presenting values of $p>0.70$ which indicated good internal consistency [41].

The result obtained according to the Spearman Brown coefficient was 0.957 for the questionnaire addressed to the teaching and management teams. The $\alpha$ for the first half was 0.966 , composed of twenty items, and 0.977 for the second half (for the remaining twenty items). For the questionnaire addressed to families, the Spearman Brown coefficient was 0.941 , and the $\alpha$ of the first half (composed of thirteen items) was 0.937 and for the second half (the remaining thirteen items) was 0.946 .

\subsection{Differences According to Gender}

In order to analyse the differences according to participant gender, Student's t-test was carried out for independent samples. Levene's test of homogeneity of variance was taken into account to estimate the equality of the variances with a significance level of $p<0.05$. For the two factors of the teaching staff questionnaire, no significant differences were found between men and women (Table 5).

Table 5. Means, standard and inferential deviations about inclusive leadership as a function of gender for the teaching staff.

\begin{tabular}{lccccccc}
\hline \multirow{2}{*}{ Factors } & \multicolumn{3}{c}{ Men } & \multicolumn{2}{c}{ Women } & \multirow{2}{*}{$\boldsymbol{t}$} & \multirow{2}{*}{$\boldsymbol{p}$} \\
\cline { 2 - 5 } & $\boldsymbol{M}$ & $\boldsymbol{S D}$ & $\boldsymbol{M}$ & $\boldsymbol{S D}$ & & \\
\hline $\begin{array}{l}\text { The school as an inclusive community } \\
\begin{array}{l}\text { Management of teaching-learning processes and } \\
\text { teachers' professional development }\end{array}\end{array}$ & 3.28 & 0.78 & 3.01 & 0.70 & 2.81 & 0.094 \\
\hline
\end{tabular}

Note: $M=$ Mean; $S D=$ Standard deviation.

The $\mathrm{t}$-test for the family questionnaire (Table 6) showed significant differences between men and women $(t=2.81 ; p<0.05)$ with respect to Factor 2, "The school as an inclusive space," with a higher value for the men.

Table 6. Means, standard and inferential deviations about inclusive leadership as a function of gender for the families.

\begin{tabular}{|c|c|c|c|c|c|c|}
\hline \multirow{2}{*}{ Factors } & \multicolumn{2}{|c|}{ Men } & \multicolumn{2}{|c|}{ Women } & \multirow{2}{*}{$t$} & \multirow{2}{*}{$p$} \\
\hline & $M$ & $S D$ & $M$ & $S D$ & & \\
\hline Openness to the community & 2.54 & 0.74 & 2.41 & 0.71 & 2.11 & 0.035 * \\
\hline The school as an inclusive space & 2.46 & 0.69 & 2.37 & 0.65 & 1.69 & 0.091 \\
\hline
\end{tabular}

Note: $M=$ Mean; $S D=$ Standard deviation; ${ }^{*} p<0.05$.

\section{Discussion and Conclusions}

The main aim of the study was to test whether the Italian versions, called Inclusive Leadership in Italian Schools [Leadership Inclusiva in Istituti Comprensivi Italiani], for the school teachers and administrators-LEI-Q-I-and for families-LEI-Q-IF-constructed from LEI-Q [23], are suitable instruments for measuring inclusive leadership in the Italian context. After analysing the processes of content validity, construct (EFA and CFA) and the reliability of the two questionnaires, it can be concluded that both are valid and reliable instruments for measuring the degree of inclusive leadership in preschool, primary and secondary education schools based on the opinion of teachers, administrators and families in the Italian context. 
After the process of translation into Italian and the experts' opinions, a good transcultural adaptation has been achieved, with clear, culturally acceptable and equivalent items, both linguistically and semantically, and the language is suitable for the target population. No reformulation, elimination or modification of any of the items was necessary. In the experts' opinion, both questionnaires present an acceptable validity of content for use in the medium of the criterion considered.

The result of the statistical analysis of the items and AFE was the existence of two factors that explain $67 \%$ of the total variance for the questionnaire addressed to the teaching team. Factor 1 --"Management of teaching-learning processes and teachers' professional development" --was made up of twenty-eight items, and Factor 2-_"The school as an inclusive community"--comprised twelve items. For AFE, the joint evaluation of a group of indices was chosen: GFI (0.997), AGFI (0.996), CFI (1.005) and RMSR (0.037), which indicated an excellent fit for these items and an acceptable model. To check the factorial structure of the questionnaire made up of two factors and forty items, an AFC was carried out through M-PLUS, obtaining favourable values-RMSEA (0.058) as SRMR (0.041), CFI (0.925) and TLI (0.919) - which indicated a good fit of the model [34].

The two factors taken from the questionnaire addressed to families explain $60.50 \%$ of the total variance: Factor 1: Openness to the community with fifteen items and Factor 2: The school as an inclusive space with eleven items. Through AFE, a GFI (0.997), AGFI (0.997), CFI (1.000) and RMSR (0.0297) were obtained, which indicated an excellent fit for these items and an acceptable model. The AFC again showed favourable and acceptable values [34]-RMSEA (0.052), SRMR (0.031), CFI (0.939) and TLI (0.933) - which demonstrated the appropriateness of the model.

The results obtained were satisfactory in terms of Cronbach's alpha coefficients, both in the totality of the questionnaires and for the two factors that make up each of them. For the LEI-Q-IP, the internal consistency of all the extracted factors can be considered highly reliable [30,42], obtaining similar values to the original instrument in Spanish in overall reliability ( $\alpha$ Spain $=0.968$ vs. $\alpha$ Italy $=0.985$ ) and in the first factor ( $\alpha$ Spain $=0.922$ vs. $\alpha$ Italy $=0.983$ ), and the second factor $(\alpha$ Spain $=0.955$ vs. $\alpha$ Italy $=0.944)$. Likewise, the LEI-Q-IF is a highly reliable instrument, obtaining higher values than the original instrument in Spanish, with the total internal consistency $(\alpha$ Spain $=0.944$ vs. $\alpha$ Italy $=0.968)$ in the first factor $(\alpha$ Spain $=0.922$ vs. $\alpha$ Italy $=0.955)$ and the second factor $(\alpha$ Spain $=0.889$ vs. $\alpha$ Italy $=$ $0.924)$ being excellent [30,42].

However, although Cronbach's alpha is the most used reliability coefficient in social sciences [40], some authors [43,44] assert that it is a biased statistic. Therefore, we have also calculated the composite reliability, obtaining very satisfactory values that are higher than the acceptability limit of 0.70 [34], thus confirming the reliability and capability of both questionnaires as instruments for measuring inclusive leadership. After the validation process, the questionnaires had the same number of items and type of scale of reply as in the original Spanish version. However, the items were not distributed in the same way. LEI-Q-IP, addressed to the teaching staff, was made up of Dimension I (from item 1 to item 12) and Dimension II (from item 13 to item 40), while in LEI-Q [23], Dimension I spanned from item 1 to 18 and Dimension II from item 19 to 40 . In the case of questionnaire LEI-Q-IF for families, Dimension I included items 1, 2, 3, 4, 5, 6, 7, 8, 9, 10 and 24, and Dimension II comprised items 11, $12,13,14,15,16,17,18,19,20,21,22,23,25$ and 26, unlike the Spanish version, which distributed items 1 to 17 to Dimension I and items 18 to 26 to Dimension II. After the analysis of the psychometric results obtained and a final check by the research team, the Italian version of both questionnaires was finalized and can be found in Appendix A.

In terms of limitations, we would point out that the selection of the participants was neither random nor probabilistic, but convenience sampling because the schools were reluctant to participate due to an inundation of questionnaires as well as the time in the school year in which they were applied (close to their assessment sessions). These aspects will be taken into account in future studies for the purpose of trying to obtain a greater number of participants. 
Another of the limitations is related to the geographical context of the participants, who are all residents of the city of Messina (Italy). In future studies, the application of the two questionnaires should be expanded to other Italian cities to confirm the results obtained here.

In conclusion, the results enable us to present a tool that, in the opinion of the teachers and the families, can tell us the way in which the schools are carrying out the tasks that promote inclusion, as well as determining what characteristics of the director and of the schools correlate positively with them.

Education authorities are increasingly assuming more responsibilities as they are held accountable for ensuring that the students are provided with an education that will help them succeed in life and in becoming active and engaged citizens. Even in a context of austerity measures, schools are expected to deliver a quality education to everyone [45].

This study corroborates the idea that school leadership practices are an important input to the quality of education. In this respect, the finding helps understand potential features of leadership (value added) that contribute to the quality of teaching and learning. In particular, the study demonstrates that the quality of inclusive school leadership must be taken into account as a key potential input that can act positively or negatively in the complex process of producing education of a given quality in every school.

Author Contributions: E.C.M., T.M. and M.J.C.C. conceived the hypothesis of this study. E.C.M., T.M. and M.J.C.C. participated in data collection. E.C.M. and M.J.C.C. analysed the data. All authors contributed to data interpretation of statistical analysis. E.C.M. and M.J.C.C. wrote the paper with significant input from E.C.M. and M.J.C.C. All authors have read and agreed to the published version of the manuscript.

Funding: This research received no external funding.

Conflicts of Interest: The authors declare no conflict of interest.

\section{Appendix A}

Table A1. Final version of questionnaires for the Italian Context.

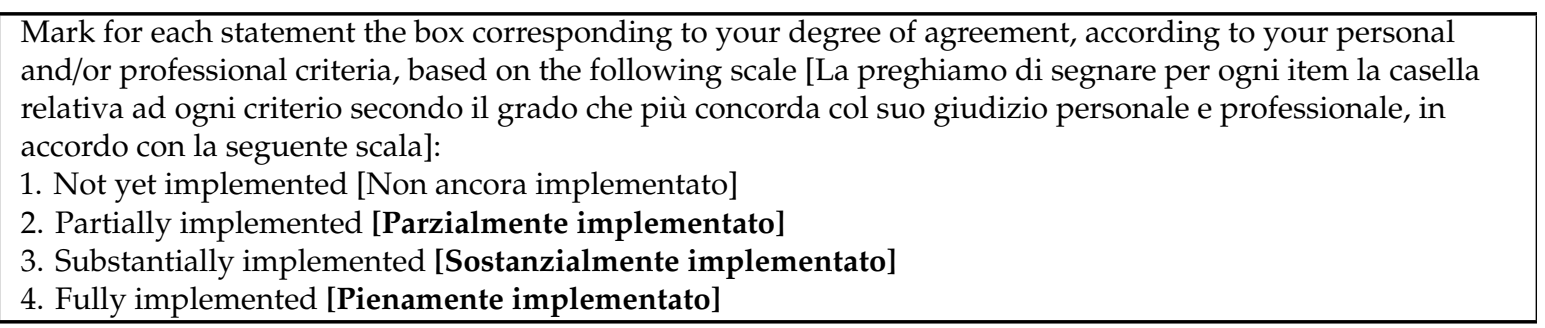

Table A2. LEI-Q-IP Questionnaire (Italian version for teachers and managerial staff).

\begin{tabular}{|c|c|c|c|c|}
\hline \multirow{2}{*}{$\begin{array}{l}\text { Dimension I. The school as an Inclusive Community [Dimensione I. La scuola come comunità inclusiva] } \\
\text { The Management Team ... [Lo Staff Di Dirigenza ... ] }\end{array}$} & \multicolumn{4}{|c|}{ Scale [Scala] } \\
\hline & 1 & 2 & 3 & 4 \\
\hline $\begin{array}{l}\text { 1. It promotes initiatives that foster the participation of community members in the educational process and in } \\
\text { the life of the school [Spinge iniziative che favoriscono la partecipazione dei membri della comunità al processo } \\
\text { formativo e alla vita dell' istituto] }\end{array}$ & & & & \\
\hline $\begin{array}{l}\text { 2. Establishes a plan of actions, developed in collaboration with other members of the community to promote } \\
\text { the school/community relations and respond to student diversity [Stabilisce un piano di azioni, elaborato in } \\
\text { sinergia con altri membri della comunità, per promuovere le relazioni scuola/comunità locale e rispondere alla } \\
\text { diversità della scolaresca] }\end{array}$ & & & & \\
\hline $\begin{array}{l}\text { 3. Promotes continuous collaboration with the business world to strengthen the school-work environmental } \\
\text { relationship [Promuove una continua collaborazione con il mondo imprenditoriale per consolidare la relazione } \\
\text { scuola-ambiente lavorativo] }\end{array}$ & & & & \\
\hline $\begin{array}{l}\text { 4. Promote actions to collaborate with other schools, to know and share experiences [Promuove azioni per } \\
\text { collaborare con altri istituti scolastici, conoscere e condividere esperienze] }\end{array}$ & & & & \\
\hline $\begin{array}{l}\text { 5. Organizes debates open to the community about situations of exclusion (racism, xenophobia, gender } \\
\text { inequality, etc.) [Organizza dibattiti aperti alla comunità su situazioni di esclusione (razzismo, } \\
\text { xenofobia, maschilismo)] }\end{array}$ & & & & \\
\hline $\begin{array}{l}\text { 6. Participates in the actions undertaken by other education institutions/organizations of the community (sports } \\
\text { activities, days against racism, etc.) [Participa alle azioni intraprese da altre istituzioni /organizzazioni della } \\
\text { comunità di carattere educativo (attività sportive, giornata contro razzismo, etc.)] }\end{array}$ & & & & \\
\hline $\begin{array}{l}\text { 7. Promotes actions to sensitize families on the importance and benefits of inclusion [Promuove azioni di } \\
\text { sensibilizzazione delle famiglie sull'importanza e i benefici dell'inclusione] }\end{array}$ & & & & \\
\hline 8. Proposes educational activities outside the school [Propone attività educative fuori dall'istituto] & & & & \\
\hline
\end{tabular}


Table A2. Cont.

\begin{tabular}{|c|c|c|c|c|}
\hline \multirow{2}{*}{$\begin{array}{l}\text { Dimension I. The school as an Inclusive Community [Dimensione I. La scuola come comunità inclusiva] } \\
\text { The Management Team ... [Lo Staff Di Dirigenza ... ] }\end{array}$} & \multicolumn{4}{|c|}{ Scale [Scala] } \\
\hline & 1 & 2 & 3 & 4 \\
\hline \multicolumn{5}{|l|}{$\begin{array}{l}\text { 9. Establishes actions that promote the real representation of the diversity of existing families in the governing } \\
\text { bodies of the school [Prevede iniziative che favoriscono la rappresentazione reale della diversità di famiglie } \\
\text { esistenti negli organi di gestione dell'istituto] }\end{array}$} \\
\hline \multicolumn{5}{|l|}{$\begin{array}{l}\text { 10. Promotes activities that foster mutual knowledge, exchange and coexistence between families and other } \\
\text { members of the school [Promuove attività che spingono la conoscenza reciproca, lo scambio e la convivenza tra } \\
\text { le famiglie e gli altri membri dell'istituzione educative] }\end{array}$} \\
\hline \multicolumn{5}{|l|}{$\begin{array}{l}\text { 11. Establishes measures to counteract the negative influence that the family situation could have on the success } \\
\text { of its students (campaigns to help, support for learning, schools for parents, support programmes) [Prevede } \\
\text { misure per contrastare l'influenza negativa che la situazione familiare potrebbe avere sul successo dei suoi } \\
\text { studenti (campagne di aiuto, sostegno all'apprendimento, incrontri con i genitori, programmi di sostegno)] }\end{array}$} \\
\hline \multicolumn{5}{|l|}{$\begin{array}{l}\text { 12. Has a procedure for collecting information on the needs of teachers, students and other school staff [Dispone } \\
\text { di una procedura di raccolta di informazione sulle necessità del corpo docente, della scolaresca e del resto del } \\
\text { personale dell'istituto] }\end{array}$} \\
\hline Dimension II. Management of teaching and learning processes and professional development of teachers & \multicolumn{4}{|c|}{ Scale [Scala] } \\
\hline $\begin{array}{l}\text { [dimensione ii. gestione dei processi di insegnamento-apprendimento e di sviluppo professionale } \\
\text { degli insegnanti] } \\
\text { The management team ... [lo staff di dirigenza ... ] }\end{array}$ & 1 & 2 & 3 & 4 \\
\hline $\begin{array}{l}\text { 13. Enables the different members of the educational community to participate in the evaluation of management } \\
\text { tasks [Permette ai diversi membri della comunità educativa di partecipare alla valutazione dei compiti } \\
\text { di gestione] }\end{array}$ & & & & \\
\hline $\begin{array}{l}\text { 14. Establishes mechanisms to promote the participation of students in the regulation of conflicts that arise in the } \\
\text { school environment [Promuove meccanismi per stimolare la partecipazione della scolaresca nella regolazione di } \\
\text { conflitti che sorgono nell'ambiente educativo] }\end{array}$ & & & & \\
\hline $\begin{array}{l}\text { 15. Encourages the students to express freely their opinion and needs (regarding their educational process, } \\
\text { standards and operation of the school, etc.) [Permette alla scolaresca di esprimere liberamente opinioni e } \\
\text { necessità (rispetto al proprio processo educativo, alle norme e al funzionamento dell'Istituto)]. }\end{array}$ & & & & \\
\hline $\begin{array}{l}\text { 16. Promotes action-research projects in the school in order to guide improvement processes [Stabilisce progetti } \\
\text { di ricerca-azione nell'istituto al fine di orientare processi di miglioramento] }\end{array}$ & & & & \\
\hline $\begin{array}{l}\text { 17. Proposes activities and designs strategies (seminars, courses, conferences, etc.) to address teachers' } \\
\text { perceptions, stereotypes, etc. in order to guarantee respect for students' diversity and equal opportunities } \\
\text { [Propone attività e progetta strategie (seminari, corsi, conferenze, etc.) per trattare le percezioni, gli stereotipi del } \\
\text { corpo docente al fine di garantire il rispetto della diversità della scolaresca e l'uguaglianza di opportunità] }\end{array}$ & & & & \\
\hline $\begin{array}{l}\text { 18. Encourages teachers to participate in educational activities organized by the local community [Favorisce la } \\
\text { partecipazione del corpo docente alle attività educative organizzate dalla comunità locale] }\end{array}$ & & & & \\
\hline $\begin{array}{l}\text { 19. Promotes a shared vision among the teachers on the organization, goals and activities to share a common } \\
\text { project with them [Favorisce tra il corpo docente una visione condivisa sull'organizzazione, le mete e le attività } \\
\text { per renderlo partecipe di un progetto commune] }\end{array}$ & & & & \\
\hline $\begin{array}{l}\text { 20. Establishes protocols to address conflicts through dialogue, mediation and negotiation among the parties } \\
\text { involved [Promuove protocolli per affrontare i conflitti attraverso il dialogo, la mediazione e la negoziazione tra } \\
\text { le parti implicate] }\end{array}$ & & & & \\
\hline $\begin{array}{l}\text { 21. Establishes sanctions for the use of symbols and actions that promote exclusion [Stabilisce sanzioni per l'uso } \\
\text { di simboli e azioni che promuovono l'esclusione] }\end{array}$ & & & & \\
\hline $\begin{array}{l}\text { 22. Develops educational programmes to prevent discriminatory attitudes among students [Sviluppa } \\
\text { programmi educativi per prevenire atteggiamenti discriminatori tra la scolaresca] }\end{array}$ & & & & \\
\hline $\begin{array}{l}\text { 23. Generates opportunities for all members of the educational community to participate effectively in decisions } \\
\text { [Crea opportunità affinché tutti i membri della comunità educativa partecipino in modo effettivo alle decisioni] }\end{array}$ & & & & \\
\hline $\begin{array}{l}\text { 24. The management team shall promote reception activities for all students and for newly-incorporated teachers } \\
\text { [Lo staff di dirigenza promuove le attività di accoglienza per tutti gli studenti e per gli insegnanti nuovi arrivati] }\end{array}$ & & & & \\
\hline $\begin{array}{l}\text { 25. Fosters activities that promote mutual knowledge among the school's students [Sostiene attività che } \\
\text { potenziano la conoscenza reciproca tra la scolaresca dell'istituto] }\end{array}$ & & & & \\
\hline $\begin{array}{l}\text { 26. Promotes collaboration among teachers to improve teaching by facilitating time and space to them } \\
\text { [Incoraggia la collaborazione tra il corpo docente, per migliorare l'insegnamento facilitando tempi e spazi] }\end{array}$ & & & & \\
\hline $\begin{array}{l}\text { 27. Be interested in knowing teachers' position on student diversity [Si preoccupa di conoscere la posizione del } \\
\text { corpo docente in relazione alla diversità della scolaresca] }\end{array}$ & & & & \\
\hline $\begin{array}{l}\text { 28. Promotes spaces for reflection among the teaching staff on the conditions of equality offered by the school } \\
\text { [Favorisce spazi di riflessione tra i membri del corpo docente sulle condizioni di uguaglianza che offre l'istituto] }\end{array}$ & & & & \\
\hline $\begin{array}{l}\text { 29. Sensitizes teachers about the need to communicate situations of discrimination or exclusion that may occur } \\
\text { in the school [Sensibilizza il corpo docente sulla necessita di comunicare situazioni di discriminazione o } \\
\text { esclusione che possano verificarsi nell'istituto] }\end{array}$ & & & & \\
\hline $\begin{array}{l}\text { 30. Organizes actions that enable the staff to reflect on their practice and and evalute the possible influence of } \\
\text { their teaching on student failure [Organizza azioni al fine di promuovere la riflessione degli insegnanti sulla loro } \\
\text { pratica educativa e di valutare il possibile impatto del loro insegnamento sull'insuccesso scolastico] }\end{array}$ & & & & \\
\hline $\begin{array}{l}\text { 31. Sensitizes teachers to have high expectations of all students [Sensibilizza il corpo docente affinché abbia alte } \\
\text { aspettative verso tutta la scolaresca] }\end{array}$ & & & & \\
\hline $\begin{array}{l}\text { 32. Be concerned that the planning of teaching is done in a coordinated way among the teaching staff [Si } \\
\text { preoccupa che la pianificazione dell'insegnamento sia fatta in modo coordinato tra il personale docente] }\end{array}$ & & & & \\
\hline $\begin{array}{l}\text { 33. Promotes a flexible and revisable curriculum to respond to the needs of students in accordance with the } \\
\text { principles of the Curriculum for All (academic, personal, social,... ) [Promuove un curriculo flessibile e } \\
\text { controllabile per dare risposta alle necessità della scolaresca concorde coi principi del Curriculum per tutti } \\
\text { (accademico, personale, sociale)] }\end{array}$ & & & & \\
\hline $\begin{array}{l}\text { 34. Promote an evaluation of curricular materials to ensure that they do not contribute to the exclusion of } \\
\text { students }\end{array}$ & & & & \\
\hline $\begin{array}{l}\text { [Si interessa di garantire l'uguaglianza di opportunità mobilitando risorse (materiali ed umane) che favoriscono } \\
\text { l'inclusione] }\end{array}$ & & & & \\
\hline $\begin{array}{l}\text { 35. Be interested in ensuring that all students are represented in the contents that are being taught [Si interessa } \\
\text { perché tutta la scolaresca si veda rappresentata nei contenuti che si insegnano] }\end{array}$ & & & & \\
\hline $\begin{array}{l}\text { 36. Promotes the continuous development of activities that enhance solidarity, empathy and assertiveness } \\
\text { among students in the classroom [Promuove il continuo sviluppo di attività che favoriscono la solidarietà, } \\
\text { l'empatia e l'assertività tra gli studenti in classe] }\end{array}$ & & & & \\
\hline $\begin{array}{l}\text { 37. Takes care that teachers set different criteria and procedures for evaluating students [Si preoccupa che il } \\
\text { corpo docente fissi criteri e procedimenti diversi per valutare la scolaresca] }\end{array}$ & & & & \\
\hline $\begin{array}{l}\text { 38. Promotes the evaluation of teaching practices to determine the degree to which they foster the inclusion of } \\
\text { students [Promuove la valutazione delle pratiche didattiche per determinare il grado in cui esse favoriscono } \\
\text { l'inclusione degli student] }\end{array}$ & & & & \\
\hline
\end{tabular}


Table A2. Cont.

\begin{tabular}{|l|c|c|c|}
\hline Dimension I. The school as an Inclusive Community [Dimensione I. La scuola come comunità inclusiva] & \multicolumn{2}{|c|}{ Scale [Scala] } \\
\cline { 2 - 4 } The Management Team ... [Lo Staff Di Dirigenza ... ] & $\mathbf{1}$ & $\mathbf{2}$ & $\mathbf{3}$ \\
\hline $\begin{array}{l}\text { 39. Ensures that evaluation has been carried out in a coordinated and interdisciplinary manner [Si adopera } \\
\text { affinchè la valutazione si realizzi in maniera coordinata ed interdisciplinare] }\end{array}$ & & & \\
\hline $\begin{array}{l}\text { 40. Encourages students' participation in the evaluation processes [Incoraggia la partecipazione degli studenti ai } \\
\text { processi di valutazione] }\end{array}$ & & & \\
\hline
\end{tabular}

Table A3. LEI-Q-IF Questionnaire (Italian version for families).

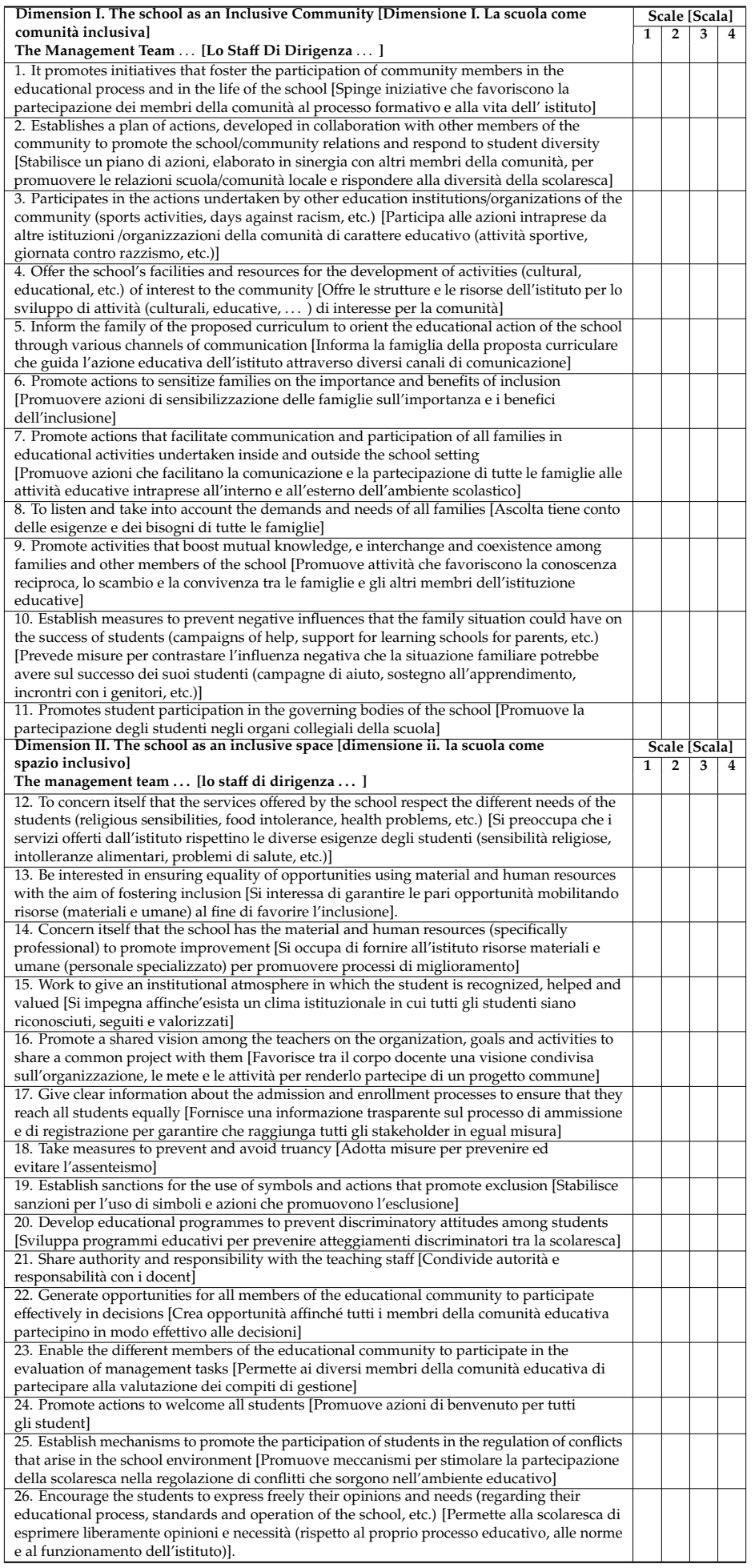




\section{References}

1. Smith, M.J. Sustainable Development Goals: Genuine global change requires genuine measures of efficacy. J. Maps. 2020, 16, i-iii. [CrossRef]

2. United Nations. We Can End Poverty: MILLENNIUM Development Goals and Beyond 2015. Available online: https://www.un.org/millenniumgoals/ (accessed on 20 February 2020).

3. Alonso-García, S.; Aznar-Díaz, I.; Cáceres-Reche, M.P.; Trujillo-Torres, J.M.; Romero-Rodríguez, J.M. Systematic Review of Good Teaching Practices with ICT in Spanish Higher Education. Trends and Challenges for Sustainability. Sustainability 2019, 11, 7150. [CrossRef]

4. Hallinger, P.; Heck, R.H. Leadership for learning: Does collaborative leadership make a difference? Educ. Manag. Adm. Lead. 2010, 38, 654-678. [CrossRef]

5. Hallinger, P.; Huber, S. School leadership that makes a difference: International perspectives. Sch. Effect. Sch. Improv. 2012, 23, 359-367. [CrossRef]

6. $\quad$ Louis, K.S.; Leithwood, K.A.; Wahlstrom, K.L.; Anderson, S.E. Learning from Leadership: Investigating the Links to Improved Student Learning; Wallace Foundation: New York, NY, USA, 2010.

7. De la Fuente-Anuncibay, R.; González-Bernal, J.; de Diego-Vallejo, R.; Caggiano, V. Liderazgo educativo en centros de secundaria. Relación con la percepción y la satisfacción laboral del profesorado. CADMO 2017, 2, 51-63. [CrossRef]

8. Agasisti, T.; Bowers, A.J.; Soncin, M. School principals' leadership types and students' achievement in the Italian context: Empirical results from a three-step Latent Class Analysis. Educ. Manag. Adm. Lead. 2019, 47, 860-886. [CrossRef]

9. Bowers, A.J. Examining a Congruency-Typology Model of Leadership for Learning using Two-Level Latent Class Analysis with TALIS 2018; OECD iLibrary: Paris, France, 2020. [CrossRef]

10. Hallinger, P. Principal Instructional Leadership: From Prescription to Theory to Practice. In The Wiley Handbook of Teaching and Learning; Hall, G.E., Quinn, L.F., Gollnick, D.M., Eds.; Wiley Blackwell: Hoboken, NJ, USA, 2018; pp. 505-528.

11. Hallinger, P. Leadership for learning: Lessons from 40 years of empirical research. J. Educ. Adm. 2011, 49, 125-142. [CrossRef]

12. Boyce, J.; Bowers, A.J. Toward an evolving conceptualization of instructional leadership as leadership for learning: Meta-narrative review of 109 quantitative studies across 25 years. J. Educ. Adm. 2018, 56, 161-182. [CrossRef]

13. Day, C.; Gu, Q.; Sammons, P. The Impact of Leadership on Student Outcomes: How Successful School Leaders Use Transformational and Instructional Strategies to Make a Difference. Educ. Adm. Quart. 2016, 52, 221-258. [CrossRef]

14. León, M.J.; Romero, A.; Navarro, R. Liderazgo inclusivo en los centros educativos. In Actas del I Congreso Internacional Educación Inclusiva en la Universidad; Universidad de Granada: Granada, Spain, 2015.

15. León, M.J.; Moreno, R. El liderazgo inclusivo en zonas desfavorecidas vs. favorecidas. In Avances en Liderazgo y Mejora de la Educación: Actas del I Congreso Internacional de Liderazgo y Mejora de la Educación; Murillo, F.J., Ed.; UAM_Biblioteca: Madrid, Spain, 2017; pp. 73-77.

16. Dettori, F. La integración de alumnos con necesidades educativas especiales en Europa: El caso de España e Italia. Rev. Educ. Incl. 2011, 4, 67-77.

17. Bezzina, C.; Paletta, A.; Alimehmeti, G. What are school leaders in Italy doing? An observational study. Educ. Manag. Adm. Lead. 2018, 46, 841-863. [CrossRef]

18. Paletta, A.; Bezzina, C. Governance and leadership in public schools: Opportunities and challenges facing school leaders in Italy. Lead. Pol. Sch. 2016, 15, 524-542. [CrossRef]

19. Paletta, A.; Basyte, E.; Alimehmet, G. How Principals Use a New Accountability System to Promote Change in Teacher Practices: Evidence from Italy. Educ. Adm. Quart. 2020, 56, 123-173. [CrossRef]

20. Hallinger, P.; Murphy, J.F. Assessing and developing principal instructional leadership. Educ. Lead. 1987, 45, 54-61.

21. Porter, A.C.; Polikoff, M.S.; Goldring, E.B.; Murphy, J.F.; Elliott, S.N.; May, H. Developing a Psychometrically Sound Assessment of School Leadership: The VAL-ED as a Case Study. Educ. Adm. Quart. 2010, 46, $135-173$. [CrossRef]

22. OCED. Mejorar el Liderazgo Escolar: Política y Prácticas; OECD Publishing: Prais, France, 2008. 
23. León, M.J.; López, M.C.; Romero, A.; Hinojosa, E.; Moreno, R. Liderando la educación inclusiva en centros de educación primaria y secundaria. In Libro de Simposios del XIV Congreso Interuniversitario de Organización de Instituciones Educativas (CIOIE); Bernal, J.L., Ed.; Universidad de Zaragoza: Zaragoza, España, 2016; pp. 127-153.

24. Lorenzo-Seva, U.; Ferrando, P.J. FACTOR: A computer program to fit the exploratory factor analysis model. Beh. Res. Meth. Instr. Comp. 2006, 38, 88-91. [CrossRef]

25. Bentler, P.M.; Yuan, K.H. Structural equation modeling with small samples: Test statistics. Mult. Beh. Res. 1999, 34, 181-197. [CrossRef]

26. Blunch, N.J. Introduction to Structural Equation Modeling Using IBM SPSS Statistics and Amos, 2nd ed.; SAGE: Thousand Oaks, CA, USA, 2013.

27. Martín Arribas, M.C. Diseño y validación de cuestionarios. Matronas Profesión 2004, 5, 23-29.

28. Escobar-Pérez, J.; Cuervo-Martínez, A. Validez de contenido y juicio de expertos: Una aproximación a su utilización. Avances en Medición 2008, 6, 27-36.

29. Schmider, E.; Ziegler, M.; Danay, E.; Beyer, L.; Bühner, M. Is it really robust? Reinvestigating the robustness of ANOVA against violations of the normal distribution assumption. Methodology 2010, 6, 147-151. [CrossRef]

30. George, D.; Mallery, P. SPSS for Windows Step-by-Step: A Simple Guide and Reference (14.0 update), 7th ed.; Allyn \& Bacon: Boston, MA, USA, 2006.

31. Lloret-Segura, S.; Ferreres-Traver, A.; Hérnandez-Baeza, A.; Tomás-Marco, I. El análisis factorial exploratorio de los ítems: Una guía práctica, revisada y actualizada. Anal. Psichol. 2014, 30, 1151-1169. [CrossRef]

32. León, M.J. La dirección de las instituciones educativas y la atención a la diversidad. In Viaje al Centro de la Dirección de Instituciones Educativas; De Vicente Rodríguez, P., Ed.; Ediciones Mensajero: Bilbao, España, 2001; pp. 399-417.

33. León, M.J. El liderazgo para y en la escuela inclusiva. Educ. Sigl. XXI 2012, 30, 131-157.

34. Hair, J.F.; Black, W.C.; Babin, B.J.; Anderson, R.E. Multivariate Data Analysis, 8th ed.; Prentice Hall: Upper Saddle River, NJ, USA 2018.

35. Timmerman, M.E.; Lorenzo-Seva, U. Dimensionality Assessment of Ordered Polytomous Items with Parallel Analysis. Psych. Meth. 2011, 16, 209-220. [CrossRef] [PubMed]

36. Kelley, T.L. Essential Traits of Mental Life, Harvard Studies in Education; Harvard University Press: Cambridge, MA, USA, 1935.

37. Carretero-Dios, H.; Pérez, C. Standards for the development and the review of instrumental studies: Considerations about test selection in psychological research. Int. J. Clin. Heal. Psychol. 2007, 7, 863-882.

38. Clark, L.A.; Watson, D. Constructing validity: Basic issues in objective scale development. In Methodological Issues E Strategies in Clinical Research, 3rd ed.; Kazdin, A.E., Ed.; APA: Washington, DC, USA, 2003; pp. $207-231$.

39. Fornell, C.; Larcker, D.F. Evaluating structural equations models with unobservable variables and measurement error. J. Mark. Res. 1981, 18, 39-50. [CrossRef]

40. Elosua, P.; Zumbo, B.D. Coeficientes de fiabilidad para escalas de respuesta categórica ordenada. Psicothema 2008, 20, 896-901.

41. Cea, D.; Ancona, M.A. Metodología Cuantitativa: Estrategias y Técnicas de Investigación Social; Síntesis: Madrid, Espala, 2001.

42. Fox, D.J. El Proceso de Investigación en Educación; Eunsa: Pamplona, España, 1987.

43. Dunn, T.J.; Baguley, T.; Brunsden, V. From alpha to omega: A practical solution to the pervasive problem of internal consistency estimation. Brith. J. Psychol. 2014, 105, 399-412. [CrossRef]

44. Netemeyer, R.G.; Bearden, W.O.; Sharma, S. Scaling Procedures: Issues and Applications; SAGE: Newcastle, UK, 2003.

45. European Commission. Draft Joint Employment Report. Brussels, Belgium. Available online: https:/eur-lex. europa.eu/legal-content/EN/TXT/PDF/?uri=CELEX:52017DC0674\&from=EN (accessed on 17 November 2018).

(C) 2020 by the authors. Licensee MDPI, Basel, Switzerland. This article is an open access article distributed under the terms and conditions of the Creative Commons Attribution (CC BY) license (http://creativecommons.org/licenses/by/4.0/). 